\title{
Corrective feedback episodes in oral interaction: A comparison of a CLIL and an EFL classroom
}

\author{
Ruth Milla \& María Pilar García MAYO* \\ Universidad del País Vasco (UPV/EHU)
}

Received: 9/03/2013. Accepted: 26/12/2013.

\begin{abstract}
This paper addresses the issue of corrective feedback (CF), a topic widely investigated in the last few decades (Sheen, 2011), and instructional context. We observed and recorded the oral interaction of an intact class of thirty Spanish intermediate-level high-school learners and two teachers in two settings: a traditional formoriented English as a Foreign Language (EFL) classroom and a meaning-oriented Content and Language Integrated Learning (CLIL) classroom (Dalton-Puffer, 2011). Corrective feedback episodes (CFE; Lyster, 1994) were used as the unit of analysis. The findings of the study indicate that there are differences in the type, quantity and manner of CFE between the two learning contexts. Although no significant difference in the proportion of learners' uptake was found between the EFL and CLIL contexts, a qualitative analysis of the data indicated that the teachers' attitude toward CF influenced subsequent learner uptake. Implications for further research on $\mathrm{CF}$, learner uptake and instructional context are suggested.
\end{abstract}

KEYWORDS: corrective feedback, oral interaction, EFL, CLIL, instructional setting.

\section{RESUMEN}

El presente trabajo versa sobre la retroalimentación correctiva (Sheen, 2011), un tema ampliamente investigado en las últimas décadas, y el contexto de instrucción. Se observó y grabó la interacción oral de una clase intacta de treinta alumnos y dos profesores de inglés como lengua extranjera (ILE), asignatura más centrada en la forma, y de aprendizaje integrado de lenguas y contenido (AICLE; Dalton-Puffer, 2011), orientada hacia el significado. La unidad de análisis utilizada fueron los episodios de retroalimentación correctiva (CFE - por sus siglas en inglés- Lyster, 1994). Los resultados muestran diferencias en tipo, cantidad y modo de los CFE entre los dos contextos. Aunque no se encontraron diferencias significativas en la respuesta de los alumnos en ILE y AICLE, el análisis cualitativo de los datos indicó que la actitud de los profesores con respecto a la retroalimentación correctiva influyó en la posterior respuesta de los alumnos a la misma. En el trabajo se sugieren líneas de trabajo para futuras investigaciones sobre la retroalimentación correctiva, la respuesta y el contexto de instrucción.

PALABRAS CLAVE: retroalimentación correctiva, interacción oral, ILE, AICLE, contexto de instrucción.

*Address for correspondence: Ruth Milla Melero. Departamento de Filología Inglesa y Alemana y Traducción e Interpretación, Facultad de Letras, Vitoria/Gasteiz, Spain. Tel: 0034 946014734; e-mail: ruth.milla@ehu.es. 


\section{INTRODUCTION}

The present study is framed within a functional approach to second language acquisition: the so-called interactionist approach (Gass \& Mackey, 2007; Long, 1996) and specifically focuses on one of its tenets: corrective feedback (CF), a reactive type of focus on form (Long, 1991). CF has been claimed to promote noticing of target forms (Schmidt, 1990; Van Patten, 1990) and facilitate second language (L2) learning (Norris \& Ortega, 2000; Russell \& Spada, 2006; Sheen, 2011; Spada, 2011).

$\mathrm{CF}$ has been widely studied and researchers have looked at the frequency and distribution of CF moves. Regarding frequency of $C F$ moves, research has found evidence of their occurrence in the classroom in a high proportion (Lochtman, 2002; Panova \& Lyster, 2002; Yoneyahm, 1982) and in a lower, but still existing, proportion in laboratory settings (Mackey et al., 2003; Oliver, 1995). A large number of studies has examined the distribution of CF types, with the result of an undoubtedly predominance of recasts (teacher's reformulation of learner's erroneous utterance providing the correct form) over other types of oral correction (Doughty, 1994; Lyster \& Ranta, 1997; Pica et al., 1989; Sheen, 2004).

As far as the effectiveness of $C F$, research has found that it has a general positive effect on learners' performance (Carroll \& Swain, 1993; Russell \& Spada, 2006; Spada, 2011). Studies have considered different variables as potential factors intervening in the effect of correction: The type of $C F$ has been widely analysed and the main findings show a tendency for further uptake to more explicit types of feedback (Norris \& Ortega, 2000; Spada 1997, 2011), such as explicit correction or metalinguistic explanations (Ellis et al., 2006; Lyster, 2004; Panova \& Lyster, 2002), especially to those types which offer opportunity for selfrepair, such as elicitation or clarification requests (Lyster \& Ranta, 1997; Lyster \& Mori, 2006). Other studies have looked at the effect of $C F$ on the acquisition of specific language features (Dabaghi \& Basturkmen, 2009; Erlam \& Loewen, 2010; Ellis et al., 2006; Sheen, 2011; Yang \& Lyster, 2010) or the influence of learners' L2 proficiency (Ammar \& Spada, 2006; Philp, 2003; Nassaji, 2010) or age (Sheen, 2004; Lyster \& Saito, 2010) on the effectiveness of CF.

Another variable that has been found to play a role on the effectiveness of $\mathrm{CF}$ is the type of instructional context. Most of the studies mentioned above have investigated CF in foreign language (FL) teaching (Dabaghi \& Basturkmen, 2009; Yang \& Lyster, 2010) or L2 learning settings (Ammar \& Spada, 2006; Panova \& Lyster, 2002; Sheen, 2007). Several researchers have compared these two contexts as far CF provision and learners' uptake (Lochtman, 2007; Lyster \& Mori, 2006; Lyster \& Saito, 2010; Sheen, 2004; Spada, 2011). Lyster and Mori (2006) carried out a descriptive study comparing a Japanese as a foreign language (JFL) and a French as a second language (FSL) classroom. They found that teachers offered $\mathrm{CF}$ in a somehow different way: although recasts where the most frequent type of $\mathrm{CF}$, the teachers in the JFL classroom tended to offer more explicit types of feedback and used 
prompts (feedback moves that push learners to self-correct, such as elicitation or metalinguistic information) more often with the intention that the learners self-repaired their errors. The researchers concluded that these teachers were concerned with language form. On the other hand, teachers in the FSL classroom followed mainly a communicative focus in their lessons and offered implicit types of correction, especially recasts. On the basis of the qualitative and quantitative analysis of the data, Lyster and Mori proposed the Counterbalance Hypothesis $(\mathrm{CH})$, which states that "[...] instructional activities and interactional feedback that act as a counterbalance to the predominant communicative orientation of a given classroom setting will be more facilitative of interlanguage (IL) restructuring than instructional activities and interactional feedback that are congruent with the predominant communicative orientation" (Lyster \& Mori, 2006: 294). That is, the claim is that those CF moves which differ from the main orientation of the lesson would be more effective. Thus, prompts would be more effective in meaning-oriented classrooms such as the FSL, and recasts would be more salient in the more form-oriented context, the JFL. In a recent meta-analysis of oral CF, Lyster and Saito (2010) did not find significant differences in the effect of CF in FL and L2 settings. However, the authors call for more qualitative types of research in order to contribute to the understanding of the contextual factors that might interfere with the effectiveness of CF types, as they only looked at the potential effect of CF in general, without looking at intervening variables, such as CF type. This is precisely one of the motivations of the present study.

A language learning context that is gaining more and more popularity in schools and universities nowadays is that instructional setting which allows for an integration of language and content, the so-called Content and Language Integrated Learning (CLIL) approach, where "[...] a foreign language is used as a tool in the learning of a non-language subject in which both language and the subject have a joint role" (Marsh, 2002: 58). In spite of the relevance of this new teaching approach, not much research has been carried out yet regarding its potential benefits for L2 learning. A small number of studies has been conducted to investigate the effects of a CLIL type of instruction on the learners' IL (Basterrechea \& García Mayo, 2013; García Mayo \& Villarreal Olaizola, 2011; Lázaro Ibarrola \& García Mayo, 2012; Lorenzo et al., 2009; Martínez Adrián \& Gutierrez Mangado, 2009; Moore, 2011). However, much more research is still needed on the effectiveness of this approach (Dalton-Puffer, 2011; García Mayo, 2011; Sierra et al., 2011). A gap in research appears in the type of correction used in these classrooms and its effectiveness in comparison to what has been found in traditional English lessons. To the best of our knowledge, Lochtman (2007) is the only study that has been carried out comparing CF in a traditional foreign language classroom and a CLIL classroom. Lochtman (2007) compared CF in FL lessons (Lochtman, 2002) with data from immersion classes (Lyster \& Ranta, 1997) and found that teachers in FL settings tend to prompt learners to self-correct errors while immersion teachers recast erroneous utterances themselves. Her results were similar to those 
reported in Lyster and Mori (2006). However, although both settings share some characteristics, immersion lessons differ from CLIL lessons in several relevant aspects such as the use of a FL in CLIL and an L2 in immersion programs, mainly non-native teachers in CLIL and native ones in immersion, and the language and content integrated focus of CLIL versus a purely content-oriented nature of immersion, among others (Lasagabaster \& Sierra, 2010). Therefore, our study aims to explore similarities and differences in EFL and CLIL settings that have not been researched regarding the issue of CF yet.

The main goal of the present exploratory study is to investigate whether context and overall lesson orientation to form (EFL) and to meaning (CLIL) influence teacher provision of $\mathrm{CF}$ and learner subsequent uptake. We have adopted corrective feedback episodes (CFEs) that occur in oral interaction among the teacher and his/her learners as the unit of analysis. CFEs are based on the error treatment sequence provided in Lyster (1994: 44) and Lyster and Mori (2006: 281). A CFE consists of three moves: learner's error, teacher's provision of CF and learner's uptake to this correction (Lyster, 1994). Example (1) below illustrates a CFE:

(1) Learner: *And the boy goed to school... (Error)

Teacher: The boy went to school (CF move in the form of a recast)

Learner: The boy went to school... (Repair move)

CF moves can be classified according to the implicitness of the correction. Figure 1 below shows the most common types of CF ordered according to the degree of explicitness, with recasts at the most implicit end and explicit correction at the opposite end and prompts (clarification requests, repetition, elicitation and metalinguistic clues) in middle positions. In this study we are interested in examining the provision and uptake of each of the types of CF and see if the general trend is towards one or the other end of the continuum of explicitness in each of the settings under study.

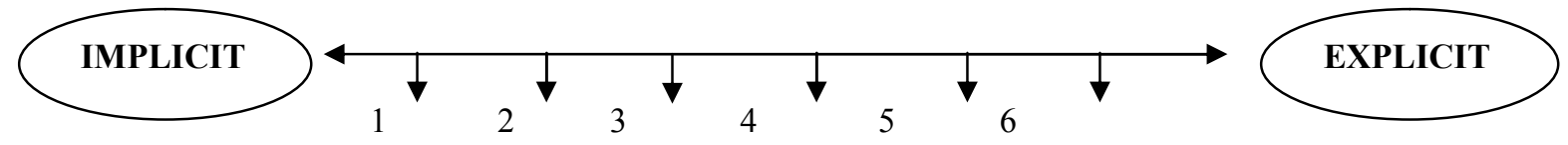

1. Recasts; 2. Clarification Request; 3. Repetition; 4. Elicitations; 5.Metalinguistic Clues; 6. Explicit Correction.

Figure 1. Continuum of the types of corrective feedback in order of explicitness.

As to the third move in the CFE, the uptake move, we may find repair of the error by the learner or there may be some problem with the repair -this would be the 'needs repair' situation. In this case, the teacher can provide further feedback or the topic can continue.

The following research questions will be entertained in this paper: 
RQ1: What type of corrective feedback (CF) do teachers provide to learners' errors in oral interaction? Is there a difference between CLIL and EFL lessons as far as type of CF is concerned?

We expected recasts to be the most frequent type of feedback, as they were so in previous studies (Doughty, 1994; Lyster \& Ranta, 1997; Pica et al., 1989, Sheen, 2004), both in FL and L2 settings. Furthermore, we expected a considerable number of prompts in the form of metalinguistic clues, clarification requests or elicitation in the EFL setting, as in Lochtman (2007) and Lyster and Mori (2006). On the other hand, we expected rare occurrences of explicit correction, as reported by previous researchers (Lyster \& Ranta, 1997).

RQ2: How do learners react to the different types of feedback in the two contexts examined? Is the instructional context an intervening factor in the effectiveness of CF?

We expected our data to conform to those reported in previous literature and show a high proportion of uptake, especially to more explicit types of feedback. Moreover, we predicted that learners would behave differently in the CLIL and in the EFL classrooms and would react differently to the different CF types (Lyster \& Mori 2006; Sheen, 2004). In other words, we expected context to influence learners' response to the different types of CF.

\section{METHOD}

\subsection{Procedure}

In order to examine oral interaction in the two contexts we followed a classroom observation procedure, as usual in this type of descriptive studies (Chaudron, 1977, 1986; Lyster \& Ranta, 1997; Panova \& Lyster, 2002). We selected two different contexts in order to compare them. On the one hand, a traditional English as a Foreign Language (EFL) classroom where the language is the learning target and where lessons will be mainly form-focused (Long \& Robinson, 1998). On the other hand, a CLIL classroom (Dalton-Puffer, 2011), where language is used as a tool to acquire content knowledge and the lessons are expected to be more oriented to meaning than in the EFL setting.

\subsection{Setting and participants}

The school selected for the study was a public high school offering post-compulsory secondary education as well as several professional courses. At the post-compulsory secondary education level the school offers a trilingual program in Spanish, Basque and English with a similar proportion of hours in each of the three languages. In order to be admitted to the program learners have to pass an English test- they are waived if they have 
attended any kind of trilingual program in compulsory secondary education (ESO) or they have an official certificate of their English level.

The learners participating in this study $(n=30)$ belonged to an intact class in the second year of post-compulsory secondary education in the trilingual program and were 16-17 years old (mean age $=16.83$ ). The learners completed a background questionnaire and the Oxford Placement Test (Syndicate, U.C.L.E., 2001). The results of this test showed that they had an intermediate proficiency level.

The learners were observed in two different contexts, Business Studies classes and English classes, with two different teachers. They had four lessons of Business Studies per week and three lessons of English language. The length of each lesson was about 50 minutes. The two participant teachers were non-native speakers of English and, when asked in informal interviews, they both showed great awareness towards the need of CF (Ferris et al., 1997; Lasagabaster \& Sierra, 2005; Lee, 2004). However, they differed in their preferences regarding the types of errors corrected and the way to provide these corrections. The English teacher was a female with 23 years of EFL teaching experience. She followed a methodology more oriented to form and reported a preference to more explicit and output-pushing feedback types. On the other hand, the teacher of Business Studies was a male teacher with a university degree in Economics and Business Studies who had been teaching for 17 years, the last 5 using English as the language of instruction. He, as many other CLIL teachers, considers language as the tool to develop content, which is the main aim of his lessons (de Graaff et al., 2007). Therefore, he tries to convey CF in an implicit way in order not to deviate learners' attention from content.

\subsection{Data collection}

Neither the teachers nor the learners were told about the specific purpose of the study. They only knew they were being recorded and observed because we were interested in their oral interaction. The idea was that they acted as naturally as possible in order to gather authentic data. That is the reason why we did not give the teachers any indication about their provision of feedback or the types of tasks that they had to carry out. Each of them used whatever activities were planned according to the course syllabus, which added to the ecological validity of the study. That is, the different activities used in both contexts actually feature what usually occurred in regular classroom sessions.

A total of seven sessions (six hours and seventeen minutes) were audio-recorded with four digital recorders (Olympus DS-5000) placed in strategic points of the classroom. We recorded three lessons of Business Studies (147 minutes) and four lessons of English language (230 minutes). During the recordings, the first author sat down at the back of the room taking notes of the verbal and non-verbal language expressed in the interaction (See Appendix for observation scheme) as well as the type of activities conducted and the organization of the lessons. This information was reflected in the researcher's notes following 
the Communicative Orientation of Language Teaching (COLT) scheme (Spada and Fröhlich, 1995).

\subsection{Data analysis}

The oral data collected were transcribed using CHILDES conventions (MacWhinney, 1995). Table 1 features the transcription codes used to classify the data on the basis of the type of error, CF moves- indicating types of correction- and uptake moves for every type of CF.

\begin{tabular}{|l|l|}
\hline CODE & MEANING \\
\hline$*$ & Error \\
\hline CC & Clarification correction \\
\hline CR & Clarification repair \\
\hline EC & Explicit correction \\
\hline ElC & Elicitation correction \\
\hline ElR & Elicitation repair \\
\hline ER & Explicit correction repair \\
\hline MC & Metalinguistic correction \\
\hline MR & Metalinguistic repair \\
\hline NR & No repair \\
\hline NU & No uptake \\
\hline RC & Recast correction \\
\hline RpC & Repetition correction \\
\hline RpR & Repetition repair \\
\hline RR & Recast repair \\
\hline Xxx & Unintelligible word or phrase \\
\hline
\end{tabular}

Table 1. Transcription codes.

Only immediate uptake was looked at, as previously done in other studies on CF. Although we cannot claim that uptake represents learning, it has been found to be indicative of some kind of awareness that could lead to interlanguage re-structuring, especially if the error is repaired (Gass \& Mackey, 2007; Long, 1996). Uptake moves in this study were grouped according to the type of CF the learners reacted to. In this case, we operationalized uptake as any reaction on the part of the learner to the CF move, no matter whether the error was repaired or not. Uptake moves in examples (2) and (3) illustrate this:

(2) Learner: who is their immediate /*Imediat/ line manager.

Teacher: immediate / I'mi:.di.ət/ [RC].

Learner: immediate / I'mi:.di.ət/ line manager [RR].

(3) Learner: he admit /*admait/ he didn't know...

Teacher: how do you say this [ElC]? 
Learner: admit /*admait/ [NR].

Example (2) belongs to the CLIL setting. The learner mispronounces the word 'immediate' and the teacher recasts the error by offering the correct form. In this case, the learner recognizes the corrective nature of the feedback move and repairs the errors by repeating the teachers' correction. Example (3) shows how the EFL teacher provides a more explicit CF move, an elicitation, to another pronunciation error. In this case, however, the learner shows uptake by reacting to the corrective move but he is not able to repair the error yet. We will see in example (9) the whole excerpt for this CFE, where the EFL teacher needs to use several feedback moves to obtain repair of this specific error.

CLAN was used to quantify the occurrences of each element of interest, as will be explained below. Fifty-six (56) minutes of classroom interaction were coded by both researchers resulting in agreement of $95 \%$ in the identification and categorization of CFEs. Once the data were collected and codified, they were quantitatively and qualitatively analyzed and compared with the results from previous related studies. The next section discusses the results obtained in the light of the predictions we had made based on the literature review.

\section{RESULTS AND DISCUSSION}

The goal of our first research question was to examine the types of CF occurring in the two contexts. As Graph 1 below shows, the EFL teacher used several correction techniques whereas the CLIL teacher mainly used recasts. However, we must take into account that the EFL teacher participating in this study provides a combination of types for the same error in most CFEs analyzed. Lyster and Ranta (1997) refer to this strategy as 'multiple feedback' provision. This type of combined correction is much richer than using a specific type of feedback, as it brings learners' attention to the errors in different ways, which clearly shows the orientation of the lesson towards form. 


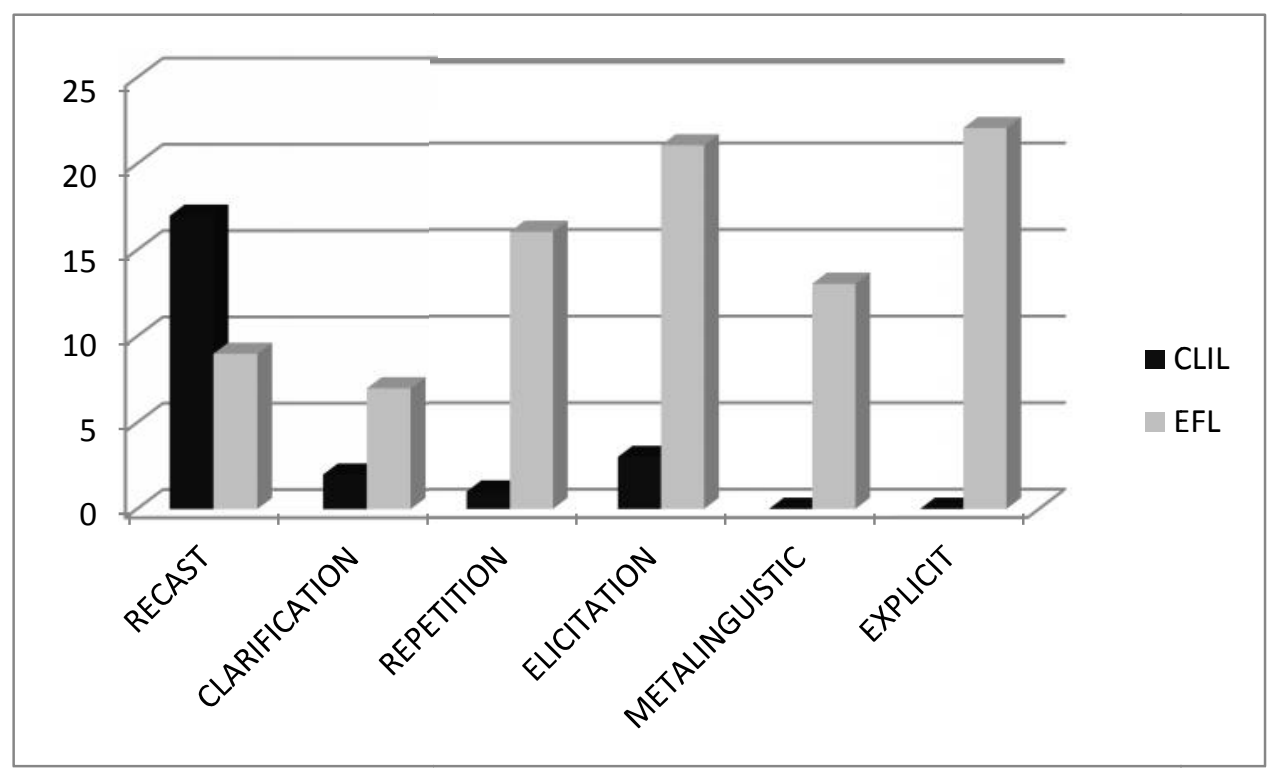

Graph 1. Types of feedback moves in CLIL and EFL lessons

Corrective moves in the EFL lessons were more explicit than in CLIL lessons, where correction was provided in a more implicit way. These results are in line with those in Lyster and Mori (2006), where the teacher in the JFL context provided more explicit correction due to the focus of the lesson, more oriented to form. Similarly, the researchers also found more occurrences of implicit correction in the more meaning-focused lessons in the FSL context. These findings seem to be in line with ours as well.

Therefore, it seems that the predictions for RQ1 are fulfilled, that is, the types of CF provided were different for each of the contexts. In order to offer a more detailed analysis of these findings, individual ANOVAs were performed to see if there was an effect of the context in the use of each of the CF types. As Table 2 shows, the two teachers only use repetition and explicit correction moves in a significantly different way. What these significant differences seem to indicate is that the EFL teacher has a clear preference for more explicit types of CF, whereas the CLIL teacher favours more implicit types. A possible reason for the lack of significance in the other types of CF moves might be found in the limited amount of moves in our database, a problem that derives from the exploratory nature of the present study and that will have to be overcome in future research.

\begin{tabular}{|l|l|l|l|}
\hline Feedback type & F-statistic & p-value & Context effect \\
\hline RECASTS & 2.45 & 0.172 & NO \\
\hline CLARIFICATION REQUESTS & 2.94 & 0.147 & NO \\
\hline REPETITION & 7.55 & 0.04 & YES $\sqrt{ }$ \\
\hline ELICITATION & 3.46 & 0.122 & NO \\
\hline METALINGUISTIC CLUES & 5.51 & 0.066 & NO \\
\hline EXPLICIT CORRECTION & 27 & 0.003 & YES $\sqrt{ }$ \\
\hline
\end{tabular}

Table 2. ANOVA 
In an attempt to provide a more in-depth analysis of our data, we have analyzed the CF moves in order to show that there is a qualitative difference in the way the EFL and the CLIL teachers approach feedback provision. Thus, in the CLIL context the most frequent (and nearly the only) type of CF move was the recast type as seen in example (2) above.

CF provision in the EFL classroom took different forms. Example (4) shows how the teacher uses different types of CF moves (the numbers in parentheses refer to each type of CF type, as follows: (1) Explicit correction, (2) Recast (written feedback), (3) Recast, (4) Repetition, (5) Metalinguistic clues, (6) Elicitation, (7) Metalinguistic clues, (8) Explicit correction, (9) Recast (written feedback)):

\section{(4) CF IN EFL}

Learner: ...instead of using the speech and rhyme to express meaning signers

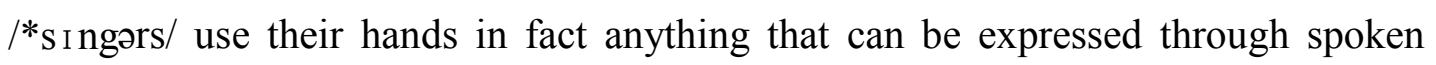

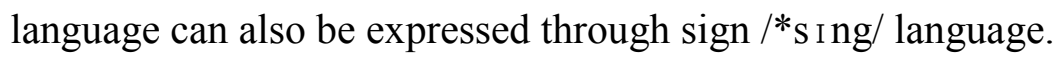

Teacher: What was the problem with their speech? There was a very big problem (1) [EC].... No it was this (Teacher writes the word 'sign' on the whiteboard (2) [RC] that their text was about sign /sa In/ language (3) [RC] and they invented a language: 'singers were singing the language' (4) $[\mathrm{RpC}]$ and you could see a person who wasn't singing at all, right? She was moving her hands! Be careful! Some pronunciation mistakes stop communication altogether! (5) [MC] How do you say this? (6) [ElC]

Learners: sign /sa In/! [ElR]

Teacher: sign /sain/ and remember that the g should be omitted it's a silent letter in English (7) [MC] so sign language, right? And you don't say singer (8) [EC], say (She writes the word 'signer' on the whiteboard) signer/sa I nə/ sign /sa In/ language signer (9) [RC].

Examples (2) and (4) illustrate the difference between both teachers: While the CLIL teacher just provides a reformulation and tries not to interrupt the learner's idea, the EFL teacher waits until the learner has finished his utterance, stops the topic and devotes time exclusively to the provision of CF. We can also notice that she does not use one type of feedback but a combination of types: This EFL teacher uses nearly the whole spectrum of CF types; even after the learners' peer-repair, she offers metalinguistic information and repeats the recasting of the word's pronunciation. She uses this strategy to bring learners' attention to the error and to try to encourage peer-repair. These two sample excerpts illustrate how CF provision differs in the two contexts. 


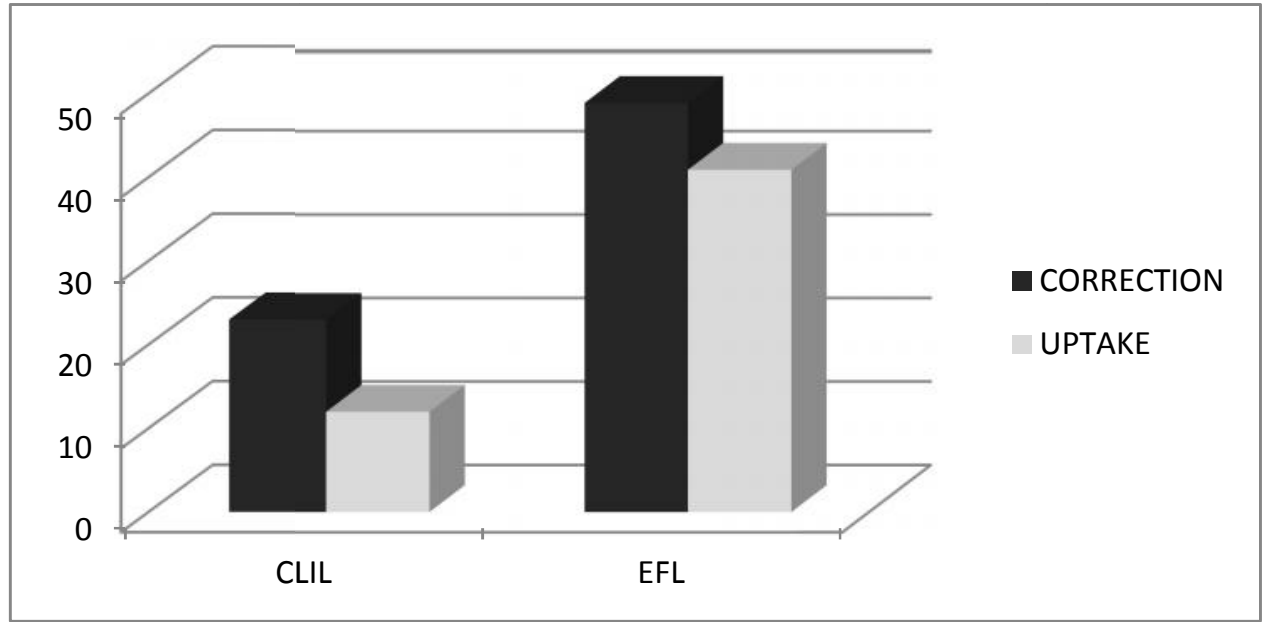

Graph 2. Correction and uptake moves in CLIL and EFL contexts

What is interesting now is to know whether the combination of CF moves was more effective for the learners than the implicit correction that the CLIL teacher provided. That is why, before looking at uptake to the specific feedback types in each of the contexts, we examined uptake in a general way in CLIL and EFL. Graph 2 shows the number of corrective moves as well as uptake moves in each context.

Overall, CF was significantly more effective in EFL (p-value $=0.00004$ ), with $82 \%$ of the CF moves obtaining learners' uptake. In CLIL, uptake was considerably lower, but still $52 \%$ of the corrections led to a response. Therefore, it seems that this combination of CF types the EFL teachers uses, or mainly the further attention to form that we have in this context, is beneficial for CF effectiveness, at least in the short term.

Our second research question aimed to explore the learners' reaction (uptake) towards the different types of CF moves in each of the settings. It also addressed the issue of whether context influenced uptake and, if it did, in which way the learners' behaviour was different. We have seen the general learners' response to CF but we were especially interested in the differences among the different types of $\mathrm{CF}$ and their corresponding learner uptake. Graph 3 features the results of uptake proportions in the two settings: 


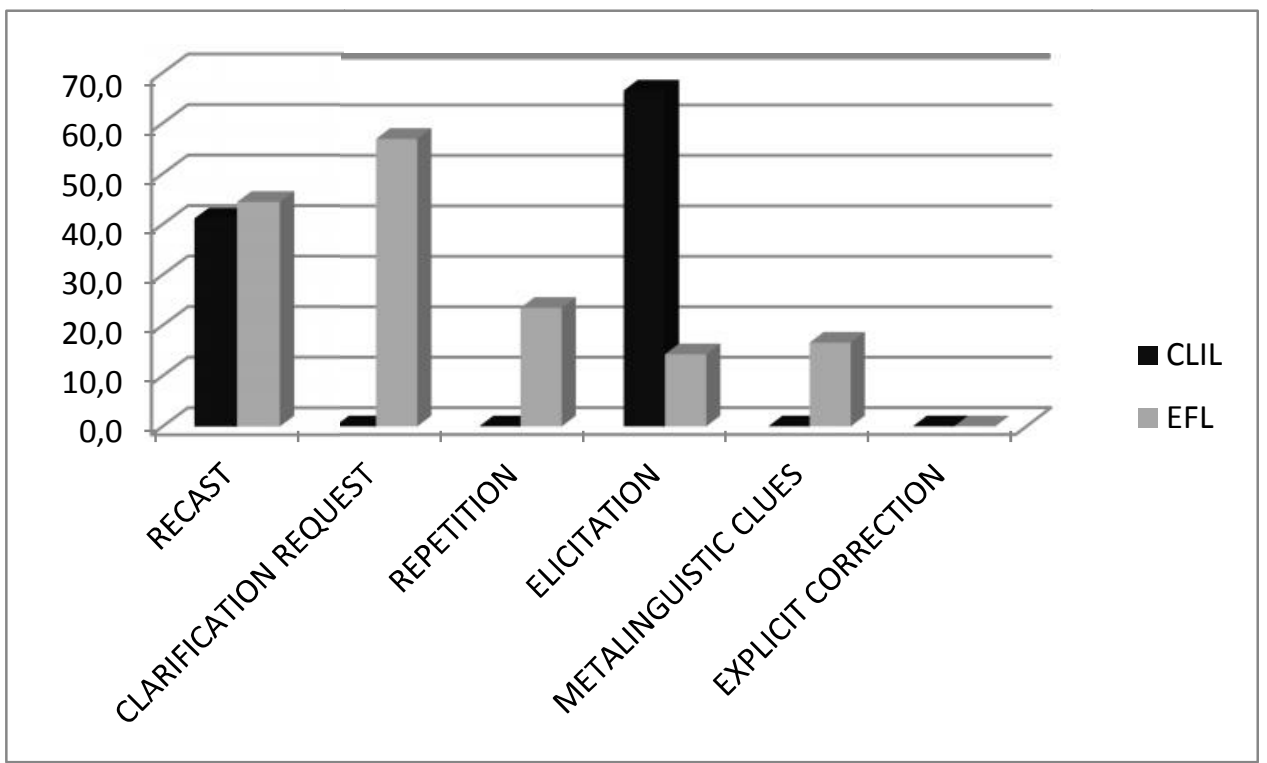

Graph 3. Proportion of uptake to the different types of feedback in each context.

Graph 3 shows that elicitation and recasts were the only CF moves that led to some learner uptake in the CLIL setting whereas there is uptake from other CF moves in the EFL setting, especially from clarification requests and recasts.

We wanted to explore whether there was an effect of context in the uptake proportion to each type of feedback. An ANOVA test showed that there was no significant difference between the proportions of uptake to each of the feedback types in the CLIL and EFL lessons $(F=0.34$ and $p$-value $=0.575)$. One of the reasons for these results might be that the contexts analysed here are not exactly the same as in Lyster and Mori (2006). Although in our study there is a setting which is more oriented to form (the EFL lesson here and the JFL classroom in Lyster and Mori's study) and another context which is more oriented to meaning or content (the CLIL lesson here and the FSL in Lyster and Mori 2006), some differences exist between the contexts in both studies. First, our CLIL context is oriented to content in a different way from the French immersion classroom. In CLIL there is a balance between content and language: language is not only part of the lesson but the tool to develop content (Coyle, 2007). Consequently, it is not surprising that the results differ from those in previous studies that include more content-oriented contexts than CLIL. Bearing these differences in mind, we will analyze these data from a more qualitative perspective and see how correction and uptake work in the specific context of our study. For this analysis, we will concentrate on those CF types which were actually used by the EFL and CLIL teachers in the present study.

On the one hand, recasts, which were frequently used in both contexts, obtained a similar proportion of uptake. Graph 3 illustrates that the proportion of uptake is not very high, just about forty per cent, and this could be due to different reasons. One of them could be the lack of salience of this type of $\mathrm{CF}$, which might prevent learners' from noticing them (Carroll, 1997; Lyster, 1998; Schachter, 1981). Another reason could be that the focus on meaning of the activities might be constraining learners' attention to form, and so, they do 
not capture the corrective nature of the reformulation (Mackey et al., 2000, 2007). In the CLIL lessons, nearly all corrections were recasts, but not all corrective moves were provided in such a way that learners had opportunities for repair. Example (5) illustrates how, after providing a morphosyntactic recast, the teacher does not offer the learner the opportunity to self-repair but, rather, goes on with the lesson.

\section{(5) RECAST IN CLIL}

Learner: the value that it has when the company start*.

Teacher: ok, when the company starts $[\mathrm{RC}]$ and do you remember that in order to calculate we have a simple formula ok? it is...? (Addressing another learner) Do you remember?

In other cases, learners were more focused on meaning and did not pay attention to recasts, as in example (6) below, which is part of a negotiation of meaning episode about the word 'limited'.

\section{(6) RECAST IN CLIL}

Learner: yes, limited is when you can lose something or the money that you have invest*...

Teacher: that you have invested invested [RC].

Learner: and unlimited when you lose the personal wealth [NU].

In the EFL classroom, as we saw above, the teacher used a combination of methods in most cases. That is why it seems that recasts were not always effective, as learners had no opportunity for repair until the teacher finished offering her multiple feedback. Let us illustrate this with example (7), where the teacher changes the topic after the correction and allows no repair move:

\section{(7) RECAST+EXPLICIT CORRECTION IN EFL}

Learner: the awards presentation ceremony which is celebrated $\mathrm{xxx}$ many artists perform xxx popular televised /*televi:zd/ xxx.

Teacher: televised /'tel. I.va Iz / [RC] no televised /*televi:zd/ [EC] televised, right, yes, so we have got that, yes, so, what do we know about it? In general what, the adjective they use to talk about the....

On the other hand, we find elicitation, a quite explicit type of feedback. In our study elicitation was hardly ever used in the CLIL lessons, as shown in Graph 1. However, this type rendered a very high proportion of uptake, which goes in line with Lyster and Mori's (2006) 
study: prompts obtained greater uptake in the more content-oriented lessons than in the more form-focused one. Let us consider an example:

(8) ELICITATION IN CLIL

Learner: yes el proceso*.

Teacher: try in English [ElC] because we are...

Learner: it is the process [EIR] where the machines do the work more...

In this study we can see that elicitation in the EFL lessons obtained a small proportion of uptake, the same as explicit correction and metalinguistic clues. We can see this in example (9) below:

\section{(9) COMBINATION OF CF TYPES IN EFL}

Learner: he admait* he didn't know (after the whole activity is corrected, she focuses on the errors)

Teacher: and some things Monica when you say I heard this admit/*admait/ [RpC] (1) but you didn't mean this at the beginning you meant $[\mathrm{ElC}](2)$ ?

Learner: eh $[\mathrm{NU}]$...

Teacher: how do you say this [ElC] (3)?

Learner: admit /*odmait/ [NR].

Teacher: no you have a double consonant here admit but it's not a present [MC] (4) so...

Learner: admit /adm It/ [MR].

Teacher: make it past [MC] (5) cause can you say it no you have to say admitted [RC] and say it.

Learner: admitted /*adm Itt/ [NR].

Teacher: admitted /adm It I d/ [RC] (6).

Learner: admitted /odmitid/ [RR].

Teacher: ok, admitted

(1) Repetition, (2) Elicitation, (3) Elicitation, (4) Metalinguistic clues, (5) Metalinguistic clues, (6) Recast

Example (8) showed how an elicitation move leads to learner repair in the CLIL classroom whereas in example (9) we can see that the EFL teacher needs to use several CF types (numbered 1-6 in example (9)). As repetition and elicitation are inefficient, she has to provide metalinguistic information, and eventually, once the learner has realized about the error but cannot repair it by himself, she provides a recast, offering the correct form. 
Nevertheless, we cannot claim that this last type is the only one that triggers repair, but probably the combination of all the types has led to the learner's noticing of the correction.

Therefore, as examples (4) and (9) illustrate, the types of correction and their combination are not identical to other studies, where each error received only one CF move, and where uptake (or absence of it) was clearly originated by the type of correction involved in each case. This difference in the use of CF types in our study might be one of the reasons why our findings are not in line with results reported in previous studies. Moreover, we must take into account that uptake in this study was limited by the teachers themselves, as we saw in examples (5) and (7) above. Besides, although results in the EFL classroom suggest that uptake was low, actually most of the errors addressed led to uptake.

Summing up, these different ways of CF provision may account for the difference in the results that we have found in the quantitative analyses of the learners' uptake. In the next section we will conclude by reviewing the interpretations and the possible implications of these results, pointing out the limitations that might have contributed to these differences too.

\section{CONCLUSIONS}

The goal of this paper was to investigate CFEs in oral interaction in two different settings: a meaning-oriented CLIL classroom and a more form-oriented classroom (EFL). Our intention was to examine the types of feedback provided in each of the settings and to consider whether there was a context effect for CF provision and learners' uptake. The study was motivated by the lack of empirical research comparing both the more established EFL approach and a CLIL approach that is becoming very popular in several countries. The present paper was inspired by the $\mathrm{CH}$ (Lyster \& Mori, 2006) and, therefore, a second goal was to examine whether this hypothesis would be of any relevance in these two learning contexts.

Results obtained from the classroom observation procedure indicate that there are differences in the types, quantity and manner of provision of CF between the two classroom contexts. A detailed qualitative analysis was carried out in order to find out to what extent the CFEs in these two settings differed. The behaviour towards CF of the two teachers participating in the study, which in turn seemed to influence learners' uptake (or absence of it), was also analyzed. In addition, the differences between our EFL context and the JFL in Lyster and Mori's (2006) study were considered as well as the different nature of our CLIL lessons and Lyster and Mori's (2006) FSL lessons.

The CLIL lesson was clearly more content-oriented than any type of EFL or ESL classroom (Coyle, 2007) and that is probably the reason why the teacher in our CLIL classroom nearly exclusively offered implicit correction. The EFL lesson was clearly more form-focused and the teacher used a wider range of CF moves to address learners' errors. 
The different settings might be accounting for the different results obtained in the two classes considered in the present study.

Although, as mentioned throughout the paper, this has been an exploratory study and findings would be hard to generalize, some of the results obtained should make us reflect on what actually occurs in real classroom settings. What this exploratory study on a CLIL and an EFL classroom has shown is that detailed classroom observation in both settings should be a must before any claim about the potential benefits of CLIL is made. Ecological validity should be seriously considered in future research comparing EFL and CLIL settings. We have shown that repetition and explicit correction were the only CF moves that were significantly different across the two settings. The EFL teacher makes frequent use of those moves and also of a richer range of $\mathrm{CF}$ techniques which, as shown in Graph 3, seem to be very effective as far as uptake is concerned. It still remains an empirical question and one in need of further research whether or not the use of $\mathrm{CF}$ that would be more salient in each instructional setting, as proposed in the $\mathrm{CH}$, would lead to further uptake by the learners.

We cannot ignore that one of the possible reasons why our results are not in line with previous literature on $\mathrm{CF}$ is the limited number of CFE observations generated. It is likely that if more data had been recorded and more CFE identified, statistics would have been more robust. Besides, the teachers' different teaching styles might be influencing the results so future research will have to include data from the same teacher in the two contexts. A third limitation is one that has been acknowledged in many studies of the kind: effectiveness has been based on learners' immediate uptake but long-term acquisition should be considered in order to assess the real impact of CF on learners' IL. As pointed out by one of the reviewers, further research on this topic should measure the impact of CF and uptake on particular target features, although this aspect was beyond the aims of the present study. Finally, we have only looked at oral correction, when maybe written feedback that learners in these contexts receive could also be examined, as suggested by Sheen (2011). Future research should take these shortcomings into account. The sample of participants needs to be increased as well as the number of lessons in order to be able to create a corpus of CFEs characteristic of each type of practice. Besides, we consider it necessary to continue the observation of both EFL and CLIL classrooms and of those individual differences in the participants that might be influencing the nature of CFEs in teacher-learner interaction.

\section{ACKNOWLEDGEMENTS}

The authors gratefully acknowledge funding from research grants IT -311-10 from the Basque Government and UFI 11/06 from the University of the Basque Country UPV/EHU. We are extremely grateful to Botikazahar high school for participating in the study and especially to the teachers Susana Hernández and Iñaki Valencia for allowing data collection in their classrooms. 


\section{REFERENCES}

Ammar, A. \& Spada, N. (2006). One size fits all? Recasts, prompts, and L2 learning. Studies in Second Language Acquisition, 28, 543-574.

Basterrechea, M. \& García Mayo, M. P. (2013). Language-related episodes during collaborative tasks: A comparison of CLIL and EFL learners (pp. 25-43). In K. McDonough \& A. Mackey (Eds.), Second Language Interaction in Diverse Educational Settings. Amsterdam: John Benjamins.

Carroll, S. (1997). The irrelevance of verbal feedback to language learning. In L. Eubank, L. Selinker \& M. Sharwood Smith (Eds.), The current state of interlanguage (pp. 73-88). Amsterdam: John Benjamins.

Carroll, S. \& Swain, M. (1993). Explicit and implicit feedback: An empirical study of the learning of linguistic generalizations. Studies in Second Language Acquisition, 15, 357-386.

Chaudron, C. (1977). A descriptive model of discourse in the corrective treatment of learners' errors. Language Learning, 27, 29-46.

Chaudron, C. (1986). Teachers' priorities in correcting learners' errors in French immersion classes. In R. R. Day (Ed.), Talking to learn. Conversation in second language acquisition (pp. 64-84). Rowley, Mass.: Newbury House.

Coyle, D. (2007). Content and language integrated learning: Towards a connected research agenda for CLIL pedagogies. International Journal of Bilingual Education and Bilingualism, 10(5), 543562.

Dabaghi, A. \& Bastkurmen, H. (2009). The effectiveness of implicit and explicit error correction on learners' performance. System, 37, 82-98.

Dalton-Puffer, C. (2011). Content and language integrated learning: from practice to principles. Annual Review of Applied Linguistics, 31, 182-204.

De Graaff, R., Koopman, G.J., Anikina, J, \& Westhoff, G. (2007). An observation tool for effective L2 pedagogy in content and language integrated learning (CLIL). International Journal of Bilingual Education and Bilingualism, 10(5), 603-624.

Doughty, C. J. (1994). Fine-tuning of feedback by competent speakers to language learners. In J. Alatis (Ed.), GURT 1993: Strategic interaction (pp. 96-108).Washington, DC: Georgetown University Press.

Ellis, R. Loewen, S. \& Erlam, R. (2006). Implicit and explicit corrective feedback and theacquisition of L2 grammar. Studies in Second Language Acquisition, 28, 339-368.

Erlam, R., \& Loewen, S. (2010). Implicit and explicit recasts in L2 oral French interaction. The Canadian Modern Language Review/La revue cannadienne des langues vivantes, 66, 877-905.

Ferris, D. R., Pezone, S., Tade, C. R., \& Tinti, S. (1997). Teacher commentary on student writing: Descriptions and implications. Journal of Second Language Writing, 6(2), 155-182.

García Mayo, M.P. (2011). The relevance of attention to L2 form in communicative classroom contexts. ELIA, 11, 11-45.

García Mayo, M.P. \& Villarreal Olaizola, I. (2011).The development of suppletive and affixal tense and agreement morphemes in the L3 English of Basque-Spanish bilinguals. Second Language Research 27(1), 129-149.

Gass, S. \& Mackey, A. (2007). Input, interaction and output. An overview. AILA Review 19, 3-17.

Lasagabaster, D. \& Sierra, J.M. (2005). Error correction: Students' versus teachers' perceptions. Language Awareness, 14 (2\&3), 112-127.

Lasagabaster, D. \& Sierra, J.M. (2010). Immersion and CLIL in English: more differences than similarities. ELT Journal 64(4), 367-375.

Lázaro Ibarrola, A. \& García Mayo, M. P. (2012). L1 use and morphosyntactic development in the oral production of EFL learners in a CLIL context. International Review of Applied Linguistics $50(2), 135-160$.

Lee, I. (2004). Error correction in L2 secondary writing classrooms: The case of Hong Kong. Journal of Second Language Writing 13(4), 285-312.

Lochtman, K. (2002). Oral corrective feedback in the foreign language classroom: How it affects interaction in analytic foreign language teaching. International Journal of Educational Research, 37, 271-283. 
Lochtman, K. (2007). Die mündliche Fehlerkorrektur in CLIL und im traditionellen Fremdsprachenunterricht: Ein Vergleich. In C. Dalton-Puffer \& U. Smit (Eds.), Empirical Perspectives on CLIL Classroom Discourse (pp. 119-138). Frankfurt a. M.: Peter Lang.

Long, M. (1991). Focus on form: A design feature in language teaching methodology. In K. De Bot, D. Coste, R. Ginsberg \& C. Kramsch (Eds.), Foreign language research in cross-cultural perspective (pp. 39-52). Amsterdam: John Benjamins.

Long, M. (1996). The Role of the Linguistic Environment in Second Language Acquisition. In W. Ritchie \& T. Bhatia (Eds.), Handbook of Second Language Acquisition (pp. 413-468). San Diego: Academic Press.

Long, M. \& Robinson, P. (1998). Focus on form: Theory, research and practice. In C. Doughty and J. William (Eds.), Focus on form in classroom second language acquisition (pp. 15-41). Cambridge: Cambridge University Press.

Lorenzo, F., Casal, S. \& Moore, P. (2009). The effects of content and language integrated learning in European education: Key findings from the Andalusian Bilingual Sections Evaluation Project. Applied Linguistics, 31(3), 418-442.

Lyster, R. (1994). The effect of functional-analytic teaching on aspects of French immersion students sociolinguistic competence. Applied Linguistics, 15, 263-287.

Lyster, R. (1998). Recasts, repetition, and ambiguity in L2 classroom discourse. Studies in Second Language Acquisition, 20, 51-81.

Lyster, R. (2004). Differential effects of prompts and recasts in form-focused instruction. Studies in Second Language Acquisition, 26, 399-432.

Lyster, R. \& Mori, H. (2006). Interactional feedback and instructional counterbalance. Studies in Second Language Acquisition, 28, 269-300.

Lyster, R., \& Ranta, L. (1997). Corrective feedback and learner uptake: Negotiation of form in communicative classrooms. Studies in Second Language Acquisition, 19, 37-66.

Lyster, R. \& Saito, K. (2010) Oral feedback in classroom SLA. A meta-analysis. Studies in Second Language Acquisition, 32, 265-302.

Mackey, A., Gass, S. and McDonough, K. (2000). How do learners perceive interactional feedback? Studies in Second Language Acquisition, 22, 471-497.

Mackey, A., Al-Khalil, M., Atanassova, G., Hama, M., Logan-Terry, A. \& Nakatsukasa, K. (2007). Teachers' intentions and learners' perception about corrective feedback in the L2 classroom. Innovations in Language Learning and Teaching, 1(10), 129-152.

Mackey, A., Oliver, R., \& Leeman, J. (2003). Interactional input and the incorporation of feedback: An exploration of NS-NNS and NNS-NNS adult and child dyads. Language Learning, 53, 3566.

MacWhinney, B. (1995). The CHILDES-Project: Tools for analyzing talk (2nd ed.). Hillsdale, NJ: Erlbaum.

Marsh, D. (2002). CLIL/EMILE- The European Dimension: Actions, trends and foresight potential. Public Services Contract DG EAC: European Commission, Brussels.

Martínez Adrián, M. \& Gutierrez Mangado, J. (2009). The acquisition of English syntax by CLIL learners. In Y. Ruiz de Zarobe \& R. C. Jiménez Catalán (Eds.), Content and language integrated learning (pp. 176-196). Bristol: Multilingual Matters.

Moore, P. (2011). Collaborative interaction in turn-taking: A comparative study of European bilingual (CLIL) and mainstream (MS) foreign language learners in early secondary education. International Journal of Bilingual Education and Bilingualism, 14(5), 531-549.

Nassaji, H. (2010). The occurrence and effectiveness of spontaneous focus on form in adult ESL classes. The Canadian Modern Language Review/La Revue cannadienne des langues vivantes, 66, 907-933.

Norris, J. \& Ortega, L. (2000). Effectiveness of L2 instruction: A research synthesis and quantitative meta-analysis. Language Learning, 50, 417-528.

Oliver, R. (1995). Negative feedback in child NS/NNS conversation. Studies in Second Language Acquisition, 17, 459-481.

Panova, I., \& Lyster, R. (2002). Patterns of corrective feedback and uptake in an adult ESL classroom. TESOL Quarterly, 36, 573-595. 
Philp, J. (2003). Constraints on noticing the gap: Nonnative speakers' noticing of recasts in NSNNS interaction. Studies in Second Language Acquisition, 25, 99-126.

Pica, T., Holliday, L., Lewis, N. \& Morgenthaler, L. (1989). Comprehensible output as an outcome of linguistic demands on the learner. Studies in Second Language Acquisition, 11, 63-90.

Russell V.J. \& Spada, N. (2006). The effectiveness of corrective feedback for second language acquisition: A meta-analysis of the research. In J. Norris \& L. Ortega (Eds.), Synthesizing research on language learning and teaching (pp. 133-164). Amsterdam: John Benjamins.

Schachter, J. (1981). The hand signal system. TESOL Quarterly, 15, 125-138.

Schmidt, R. (1990) The role of consciousness in L2 learning. Applied Linguistics, 11, 129-158.

Sheen, Y. (2004). Corrective feedback and learner uptake in communicative classrooms across instructional settings. Language Teaching Research, 8, 263-300.

Sheen, Y. (2007). The effects of corrective feedback, language aptitude and learner attitudes on the acquisition of English articles. In A. Mackey (Ed.), Conversational interaction in second language acquisition: A collection of empirical studies (pp. 301-322). Oxford: Oxford University Press.

Sheen, Y. (2011). Corrective feedback, individual differences and second language learning. New York: Springer.

Sierra, J., Gallardo del Puerto, F. \& Ruiz de Zarobe, Y. (2011). Good practices and future actions in CLIL: Learning and pedagogy. In J. M. Sierra, F. Gallardo del Puerto \& Y. Ruiz de Zarobe (Eds.), Content and foreign language integrated learning: Contributions to multilingualism in european contexts (pp. 317-339). Bern: Peter Lang.

Spada, N. (1997). Form-focused instruction and second language acquisition: A review of classroom and laboratory research. Language Teaching, 29, 73-87.

Spada, N. (2011). Beyond form-focused instruction: Reflections on past, present and future research. Language Teaching, 44, 225-236.

Spada, N. \& Fröhlich, M. (1995). COLT. Communicative orientation of language teaching observation scheme: Coding conventions and applications. Sydney: National Centre for English Language Teaching Research.

Syndicate, U.C.L.E (2001). Quick Placement Test. Oxford: Oxford University Press.

Van Patten, B. (1990). Attending to content and form in the input: An experiment in consciousness. Studies in Second Language Acquisition, 12, 287-301.

Yang, Y. \& Lyster, R. (2010). Effects of form-focused practice and feedback on Chinese EFL learners' acquisition of regular and irregular past tense forms. Studies in Second Language Acquisition, $32,235-263$.

Yoneyahm, A. (1982). The treatment of learners' errors by novice EFL teachers. Bulletin of the College of Education, Human and Social Sciences, 23, 85-94. 


\section{APPENDIX: OBSERVATION SCHEME}

Classroom/Subject:

Date:
No of learners:

Time:
Teacher:

\begin{tabular}{|l|l|l|l|l|l|}
\hline Student's error & Type & Teacher's feedback & Type & Learner's uptake & Type \\
\hline & & & & & \\
\hline
\end{tabular}

Type of error: M-morphosyntactic, L-lexical, P-phonological, 1-L1 use (Basque or Spanish) Type of feedback: R-recast, CL-clarification request, Rp-repetition, E- Elicitation, M-metalinguistic info, EC-explicit correction

Type of uptake: R-repair, NR-needs repair, NU-no uptake 